ISSN: 1896-4087

DOI: http://dx.doi.org/10.21784/ZC.2018.005

\title{
Podatek od nieruchomości - aktualne problemy po ostatnich nowelizacjach ustawy o podatkach i opłatach lokalnych
}

\author{
Real estate tax - the current problems after last amendments \\ of The Local Taxes and Fees Act
}

\begin{abstract}
Abstrakt:
Niniejszy artykuł poświęcony został nowelizacji art. 3 ust. 5 ustawy o podatkach i opłatach lokalnych dotyczącej opodatkowania gruntu oraz części budynku stanowiących nieruchomość wspólną. Przedstawione zostały w nim rozwiązania funkcjonujące do dnia 31 grudnia 2015 r., jak i nowy stan prawny, obowiązujący od dnia 1 stycznia 2016 r. Autor wskazuje na podstawowe problemy w stosowaniu znowelizowanego przepisu w zakresie opodatkowania podatkiem od nieruchomości części wspólnej, w szczególności problemy spowodowane brakiem przekazania przez wspólnotę mieszkaniową informacji o jej powierzchni.
\end{abstract}

Słowa kluczowe: podatek od nieruchomości; wspólnota mieszkaniowa; nieruchomość wspólna.

\begin{abstract}
:
This publication applies to amending Art. 3 sec. 5 of The Local Taxes and Fees Act which pertain to taxation of land and parts of the building posing a common property. It presents solutions in both the old legal status, before of the $31^{\text {st }}$ of December 2015 and the new legal status, from the $1^{\text {st }}$ of January 2016. The author presents the current problems applying the new tax regulation about of real estate taxation common property, especially problems caused by the lack of information from the housing cooperative (condominium) about the area of common property.
\end{abstract}

Keywords: real estate tax; housing cooperative (condominium); common property. 
Adam Mudław - Podatek od nieruchomości - aktualne problemy...

\section{Wprowadzenie}

Od 1 stycznia 2016 roku ustawa z dnia 12 stycznia 1991 roku o podatkach i opłatach lokalnych ${ }^{1}$ przechodziła szereg mniej lub bardziej istotnych nowelizacji, wpływających na zasady opodatkowania gruntów, budynków i budowli podatkiem od nieruchomości.

Do kluczowych zmian, które zostały wprowadzone z dniem 1 stycznia 2016 roku do ustawy o podatkach i opłatach lokalnych zaliczyć należy:

- wyłączenie z definicji działalności gospodarczej działalności rolników w zakresie sprzedaży, o której mowa w art. 20 ust. 1c ustawy z dnia 26 lipca 1991 roku o podatku dochodowym od osób fizycznych $^{2}$ - vide: postanowienia art. 1a ust. 2 pkt 3 ustawy o podatkach i opłatach lokalnych wprowadzone na mocy art. 2 ustawy z dnia 9 kwietnia 2015 roku o zmianie ustawy o podatku dochodowym od osób fizycznych oraz niektórych innych ustaw ${ }^{3}$,

- zmiany wprowadzone na mocy art. 9 ustawy z dnia 25 czerwca 2015 roku o zmianie ustawy o samorządzie gminnym oraz niektórych

\footnotetext{
${ }^{1}$ Tekst jednolity: Dz.U. z 2016 r., poz. 716 z późn. zm.

${ }^{2}$ Stosownie do treści art. 20 ust. 1c ustawy z dnia 26 lipca 1991 roku o podatku dochodowym od osób fizycznych (tekst jednolity: Dz.U. z 2016 r., poz. 2032, z późn. zm.) za przychody z innych źródeł, o których mowa w art. 10 ust. 1 pkt 9, uważa się również przychody ze sprzedaży przetworzonych w sposób inny niż przemysłowy produktów roślinnych i zwierzęcych pochodzących z własnej uprawy, hodowli lub chowu, z wyjątkiem przetworzonych produktów roślinnych i zwierzęcych uzyskanych w ramach prowadzonych działów specjalnych produkcji rolnej oraz produktów opodatkowanych podatkiem akcyzowym na podstawie odrębnych przepisów, jeżeli:

1) sprzedaż nie jest wykonywana na rzecz osób prawnych, jednostek organizacyjnych nieposiadających osobowości prawnej lub na rzecz osób fizycznych na potrzeby prowadzonej przez nie pozarolniczej działalności gospodarczej;

2) przetwarzanie produktów roślinnych i zwierzęcych i ich sprzedaż nie odbywa się przy zatrudnieniu osób na podstawie umów o pracę, umów zlecenia, umów o dzieło oraz innych umów o podobnym charakterze;

3) sprzedaż następuje wyłącznie:

a) w miejscach, w których produkty te zostały wytworzone,

b) na targowiskach, przez które rozumie się wszelkie miejsca przeznaczone do prowadzenia handlu, z wyjątkiem sprzedaży dokonywanej w budynkach lub w ich częściach;

4) prowadzona jest ewidencja sprzedaży, o której mowa w ust. 1e;

5) podatnik nie uzyskał innych przychodów ze źródła, o którym mowa w art. 10 ust. 1 pkt 3.

${ }^{3}$ Dz.U. z 2015 r., poz. 699.
} 
innych ustaw ${ }^{4} \mathrm{w}$ zakresie doprecyzowania pojęcia działalności gospodarczej jak i gruntów, budynków i budowli związanych z prowadzeniem działalności gospodarczej, w zakresie zmiany zasad odpowiedzialności solidarnej za zobowiązanie podatkowe, zmiany opodatkowania udziału w nieruchomości wspólnej, w zakresie niewszczynania postępowania podatkowego odnośnie niskich zobowiązań podatkowych, jak również zmiany dotyczące niektórych zwolnień w zakresie podatku od nieruchomości,

- wprowadzenie zwolnienia z podatku od nieruchomości gruntów i budynków lub ich części, stanowiących własność gminy, z wyjątkiem zajętych na działalność gospodarczą lub będących w posiadaniu innych niż gmina jednostek sektora finansów publicznych oraz pozostałych podmiotów - vide: postanowienia art. 7 ust. 1 pkt 15 ustawy o podatkach i opłatach lokalnych wprowadzone na mocy art. 1 ustawy z dnia 23 lipca 2015 roku o zmianie ustawy o podatkach i opłatach lokalnych ${ }^{5}$,

- wprowadzenie do ustawy stawek dla gruntów niezabudowanych objętych obszarem rewitalizacji oraz wyłączenie tych gruntów z zakresu pojęcia gruntów, budynków i budowli związanych z prowadzeniem działalności gospodarczej - vide: postanowienia art. 1a ust. 2a pkt 2 oraz art. 5 ust. 1 pkt 1 lit. d) ustawy o podatkach i opłatach lokalnych wprowadzone na mocy art. 37 ustawy z dnia 9 października 2015 roku o rewitalizacji ${ }^{6}$,

- wprowadzenie wyłączenia z opodatkowania podatkiem od nieruchomości urzędów związków metropolitalnych - vide: postanowienia art. 2 ust. 3 pkt 3 ustawy o podatkach i opłatach lokalnych wprowadzone na mocy art. 55 ustawy z dnia 9 października 2015 roku o związkach metropolitalnych ${ }^{7,8}$.

${ }^{4}$ Dz.U. z 2015 r., poz. 1045.

${ }^{5}$ Dz.U. z 2015 r., poz. 1283.

${ }^{6}$ Dz.U. z 2015 r., poz. 1777.

${ }^{7}$ Dz.U. z 2015 r., poz. 1890.

${ }^{8}$ W kwestii zmian w podatku od nieruchomości w 2016 roku zob. również: W. Morawski, Zmiany w regulacji podatku od nieruchomości w 2016 roku - drobne remonty w skansenie, „Przegląd Podatkowy” 2016, nr 11. 
Adam Mudław - Podatek od nieruchomości - aktualne problemy...

Z dniem 1 stycznia 2017 roku na mocy art. 2 ustawy z dnia 16 listopada 2016 roku o zmianie ustawy o transporcie kolejowym oraz niektórych innych ustaw ${ }^{9}$ zmodyfikowano zwolnienie z podatku od nieruchomości gruntów, budynków i budowli wchodzących w skład infrastruktury kolejowej w rozumieniu przepisów o transporcie kolejowym $^{10}$. Z kolei z dniem 14 lipca 2017 roku mocy art. 2 ustawy z dnia 25 maja 2017 roku o zmianie ustawy o podatku rolnym, ustawy o podatkach i opłatach lokalnych oraz ustawy o podatku leśnym ${ }^{11}$ po raz kolejny zmieniono zasady odpowiedzialności solidarnej za zobowiązanie podatkowe w podatku od nieruchomości ${ }^{12}$.

Na wstępie wskazać należy, iż ustawodawca niestety nie zdecydował się na stworzenie nowej regulacji prawnej dotyczącej podatków i opłat lokalnych, w tym podatku od nieruchomości, przyjmując drogę nowelizowania archaicznych rozwiązań ${ }^{13}$, które rodzą wiele problemów. Tematem niniejszej publikacji jest analiza zmiany postanowień art. 3 ust. 5 ustawy o podatkach i opłatach lokalnych dotyczących opodatkowania gruntu oraz części budynku stanowiących nieruchomość wspólną.

\section{Stan prawny obowiązujący do dnia 31 grudnia 2015 roku}

Przepisy ustawy o podatkach i opłatach lokalnych wprowadzają specyficzne zasady opodatkowania części wspólnej gruntu i budynku stanowiącego współwłasność. W stanie prawnym obowiązującym do dnia 31 grudnia 2015 roku, zgodnie z art. 3 ust. 5 ustawy o podatkach i opłatach lokalnych, jeżeli wyodrębniono własność lokali, obowiązek podatkowy w zakresie podatku od nieruchomości od gruntu oraz części budynku stanowiących współwłasność ciążył na właścicielach lokali w zakresie odpowiadającym częściom ułamkowym wynikającym

\footnotetext{
${ }^{9}$ Dz.U. z 2016 r., poz. 1923.

${ }^{10}$ Zob. art. 7 ust. 1 pkt 1 ustawy o podatkach i opłatach lokalnych.

${ }^{11}$ Dz.U. z 2017 r., poz. 1282.

${ }^{12}$ Zob. art. 3 ust. 4 i 6 ustawy o podatkach i opłatach lokalnych.

${ }^{13}$ Por. L. Etel, 20 lat ustawy o podatkach i opłatach lokalnych - kilka refleksji, „Przegląd Podatkowy" 2011, nr 4.
} 
ze stosunku powierzchni użytkowej lokalu do powierzchni użytkowej całego budynku. Z kolei stosownie do treści art. 1a ust. 5 pkt 5 ustawy o podatkach i opłatach lokalnych powierzchnią użytkową budynku lub jego części powierzchnia mierzona po wewnętrznej długości ścian na wszystkich kondygnacjach, z wyjątkiem powierzchni klatek schodowych oraz szybów dźwigowych; za kondygnację uważa się również garaże podziemne, piwnice, sutereny i poddasza użytkowe.

„Dane dotyczące powierzchni użytkowej powinny być ustalane $\mathrm{w}^{2}$ na podstawie fizycznego obmiaru powierzchni budynku po wewnętrznej długości ścian. Jest to dosyć skomplikowana operacja, zwłaszcza przy budynkach o zróżnicowanej wysokości. Obmiaru dokonuje podatnik i wykazuje powierzchnię użytkową w informacji bądź deklaracji. Tego sposobu ustalania powierzchni nie można zastępować danymi np. $\mathrm{z}$ aktu notarialnego lub projektu architektonicznego budynku" ${ }^{14}$.

Sposób obliczania powierzchni wspólnej podlegającej opodatkowaniu podatkiem od nieruchomości można przedstawić na następującym przykładzie. W budynku znajdują się cztery jednakowe mieszkania o powierzchni użytkowej $60 \mathrm{~m}^{2}$ każdy. Powierzchnia użytkowa całego budynku wynosi $460 \mathrm{~m}^{2}$. Powierzchnia części wspólnych, na który składają się m.in. piwnice i poddasza użytkowe, to $220 \mathrm{~m}^{2}$. Do nieruchomości przynależy grunt będący współwłasnością właścicieli lokali o powierzchni $500 \mathrm{~m}^{2}$.

W celu obliczenia podatku od nieruchomości od części wspólnej budynku oraz gruntu przypadających na właściciela jednego mieszkania należało ustalić proporcję, w jakiej powierzchnia użytkowa tego mieszkania pozostaje do powierzchni użytkowej całego budynku. Wyliczenie przedstawia się następująco:

$$
60 \mathrm{~m}^{2} / 460 \mathrm{~m}^{2}=0,13=13 \% .
$$

Następnie wyliczoną proporcję stosujemy do obliczenia podstawy opodatkowania powierzchni stanowiących część wspólną budynku i gruntu:

\footnotetext{
${ }^{14}$ Por. L. Etel, [w:] L. Etel, S. Presnarowicz, G. Dudar (red.), Podatki i opłaty lokalne, Podatek rolny, Podatek leśny. Komentarz, Warszawa 2008, s. 55. Zob. również B. Dauter (red.), Podatki i opłaty lokalne, Podatek rolny, Podatek leśny, Warszawa 2009, s. 23 oraz s. 41.
} 
Adam Mudław - Podatek od nieruchomości - aktualne problemy...

$$
\begin{gathered}
220 \mathrm{~m}^{2} \times 13 \%=28,6 \mathrm{~m}^{2} \text { (część wspólna budynku), } \\
500 \mathrm{~m}^{2} \times 13 \%=65 \mathrm{~m}^{2} \text { (grunt). }
\end{gathered}
$$

Z pozoru jasna i precyzyjnie wskazana przez ustawodawcę metoda liczenia proporcji sprawiała wiele problemów, które bardzo często miały swój finał przed sądami administracyjnymi. „Część organów podatkowych, wbrew jasnemu, jednoznacznemu brzmieniu art. 3 ust. 5 ustawy o podatkach i opłatach lokalnych opowiadała się za innym ustalaniem proporcji, według której powinien być obliczany podatek od nieruchomości od części wspólnej. Zdaniem organów podatkowych proporcja ta powinna być ustalana jako udział powierzchni użytkowej wyodrębnionego lokalu w łącznej powierzchni wszystkich wyodrębnionych lokali, zamiast w łącznej powierzchni użytkowej całego budynku"15. W analizowanym powyżej przykładzie wyliczenie to wyglądałoby następująco:

$$
\begin{gathered}
60 \mathrm{~m}^{2} / 240 \mathrm{~m}^{2}=0,25=25 \%, \\
220 \mathrm{~m}^{2} \times 25 \%=55 \mathrm{~m}^{2} \text { (część wspólna budynku), } \\
500 \mathrm{~m}^{2} \text { x } 25 \%=125 \mathrm{~m}^{2} \text { (grunt). }
\end{gathered}
$$

Sądownictwo administracyjne w sposób jednoznaczny wskazało, iż forsowany przez organy podatkowe sposób ustalania proporcji nie może mieć zastosowania, albowiem jest on sprzeczny z jasnymi oraz precyzyjnymi postanowieniami art. 3 ust. 5 ustawy o podatkach i opłatach lokalnych. Wskazać tutaj należy wyrok Naczelnego Sądu Administracyjnego z dnia 13 listopada 2012 roku $^{16}$, w którym Sąd podkreślił, iż: „(...) treść art. 3 ust. 4-5 ustawy o podatkach i opłatach lokalnych nie nasuwa $\mathrm{w}$ warstwie literalnej zastrzeżeń. Stąd też ustaleń interpretacyjnych dokonanych w tym trybie nie sposób kwestionować ze względów systemowych, czy też funkcjonalnych".

Z kolei w wyroku z dnia 27 października 2015 roku ${ }^{17}$ WSA w Bydgoszczy expressis verbis wskazał, iż: „obowiązek podatkowy został

\footnotetext{
${ }^{15}$ Por. Ł. Kupień, Opodatkowanie części wspólnej nieruchomości od 1 stycznia 2016 roku, Publikacje Elektroniczne ABC LEX Wolters Kluwer.

${ }^{16}$ Sygn. akt II FSK 647/11, LEX nr 1232315.

${ }^{17}$ Sygn. akt I SA/Bd 660/15, LEX nr 1929343.
} 
w art. 3 ust. 5 ustawy o podatkach i opłatach lokalnych wyrażony ułamkiem, w którym w mianowniku jest powierzchnia użytkowa całego budynku. (...) Proporcja, o której mowa w art. 3 ust. 5 ustawy o podatkach i opłatach lokalnych, została uzależniona od powierzchni użytkowej budynku, w którym wyodrębniono lokal, a nie od łącznej powierzchni użytkowej wszystkich lokali wraz z pomieszczeniami do nich przynależnymi znajdujących się na danej nieruchomości". Podobnie wypowiedział się WSA w Gliwicach w wyroku z dnia 9 lipca 2015 roku $^{18}$, WSA w Poznaniu w wyroku z dnia 21 maja 2015 roku $^{19}$, czy WSA w Łodzi w wyroku z dnia 9 kwietnia 2015 roku $^{20}$.

Wskazać w tym miejscu należy, iż stosowanie przepisu art. 3 ust. 5 ustawy o podatkach i opłatach lokalnych budziło wiele wątpliwości, albowiem korzystanie z wyliczonej według powyższej normy prawnej proporcji powodowało, że część nieruchomości wspólnej nie podlegała opodatkowaniu podatkiem od nieruchomości. Jak wskazywała doktryna „problem ten jest przykładem oczywistego błędu ustawodawcy”21. Przepis ten, pomimo iż stosując wykładnię językową nie budził wątpliwości, sprzeczny był z zasadami logiki, ponieważ powodował lukę w opodatkowaniu powierzchni części wspólnej podatkiem od nieruchomości ${ }^{22}$.

\section{Stan prawny obowiązujący od dnia 1 stycznia 2016 roku}

W dniu 25 czerwca 2015 r. uchwalona została ustawa o zmianie ustawy o samorządzie gminnym oraz niektórych innych ustaw ${ }^{23}$. Na mocy art. 9 pkt 4 lit. c) ww. ustawy zmianie uległa treść przepisu art. 3 ust. 5 ustawy o podatkach i opłatach lokalnych. W obecnym stanie prawnym,

\footnotetext{
${ }^{18}$ Sygn. akt I SA/Gl 64/15, LEX nr 1789332.

${ }^{19}$ Sygn. akt I SA/Po 155/15, LEX nr 1806968.

${ }^{20}$ Sygn. akt I SA/Łd 8/15, LEX nr 1746586.

${ }^{21}$ Por. W. Morawski (red.), Ustawa o podatkach i opłatach lokalnych. Komentarz, Gdańsk 2013, s. 229.

${ }^{22}$ Zob. również: P. Borszowski, Komentarz do art. 3ustawy o podatkach i opłatach lokalnych, [w:] Podatki i opłaty lokalne. Podatek rolny. Podatek leśny. Komentarz, Warszawa 2016, Publikacje Elektroniczne ABC LEX Wolters Kluwer.

${ }^{23}$ Dz.U. z 2015 r., poz. 1045.
} 
stosownie do postanowień art. 3 ust. 5 ustawy o podatkach i opłatach lokalnych jeżeli wyodrębniono własność lokali, obowiązek podatkowy w zakresie podatku od nieruchomości od gruntu oraz od części budynku stanowiących nieruchomość wspólną w rozumieniu art. 3 ustawy z dnia 24 czerwca 1994 r. o własności lokali ${ }^{24}$ ciąży na właścicielach w zakresie odpowiadającym ich udziałowi w nieruchomości wspólnej.

Przepis powyższy odwołuje się w swojej treści do postanowień art. 3 ustawy z dnia 24 czerwca 1994 r. o własności lokali, który stanowi, iż w razie wyodrębnienia własności lokali, właścicielowi lokalu przysługuje udział w nieruchomości wspólnej jako prawo związane z własnością lokali. Nie można żądać zniesienia współwłasności nieruchomości wspólnej, dopóki trwa odrębna własność lokali. Nieruchomość wspólną stanowi grunt oraz części budynku i urządzenia, które nie służą wyłącznie do użytku właścicieli lokali. Udział właściciela lokalu wyodrębnionego w nieruchomości wspólnej odpowiada stosunkowi powierzchni użytkowej lokalu wraz z powierzchnią pomieszczeń przynależnych do łącznej powierzchni użytkowej wszystkich lokali wraz z pomieszczeniami do nich przynależnymi. Udział właściciela samodzielnych lokali niewyodrębnionych w nieruchomości wspólnej odpowiada stosunkowi powierzchni użytkowej tych lokali wraz z powierzchnią pomieszczeń przynależnych do łącznej powierzchni użytkowej wszystkich lokali wraz z pomieszczeniami do nich przynależnymi. Na potrzeby stosowania ustawy o własności lokali przyjmuje się, że udział w nieruchomości wspólnej współwłaściciela lokalu w częściach ułamkowych odpowiada iloczynowi wielkości jego udziału we współwłasności lokalu i wielkości udziału we współwłasności nieruchomości wspólnej przypadającej na ten lokal. Do wyznaczenia stosunku, o którym mowa powyżej, niezbędne jest określenie, oddzielnie dla każdego samodzielnego lokalu, jego powierzchni użytkowej wraz z powierzchnią pomieszczeń do niego przynależnych. Jeżeli nieruchomość, z której wyodrębnia się własność lokali, stanowi grunt zabudowany kilkoma budynkami, udział właściciela lokalu wyodrębnionego

${ }^{24}$ Tekst jednolity: Dz. U. z 2015 r., poz. 1892. 
w nieruchomości wspólnej odpowiada stosunkowi powierzchni użytkowej lokalu wraz z powierzchnią pomieszczeń przynależnych do łącznej powierzchni użytkowej wszystkich lokali wraz z pomieszczeniami do nich przynależnymi. W wypadku gdy na podstawie jednej czynności prawnej dokonanej przez właściciela lub przez wszystkich współwłaścicieli nieruchomości następuje wyodrębnienie wszystkich lokali, wysokość udziałów w nieruchomości wspólnej, określają odpowiednio w umowie właściciel lub współwłaściciele.

W uzasadnieniu wprowadzenia zmian $\mathrm{w}$ art. 3 ust. 5 ustawy o podatkach i opłatach lokalnych wskazano, iż nadanie nowego brzmienia wymienionemu przepisowi „umożliwi objęcie podatkiem całej powierzchni stanowiącej współwłasność istniejącą w związku z odrębną własnością lokali. W obecnym stanie prawnym ${ }^{25}$ literalne stosowanie art. 3 ust. 5 powoduje, że w przypadku wyodrębnienia w budynku własności lokali, ciążący na właścicielach lokali obowiązek podatkowy od gruntu oraz od części budynku stanowiących współwłasność nie obejmuje całej powierzchni gruntu oraz powierzchni użytkowej budynku stanowiącej współwłasność (części wspólnej)”26. Dlatego też postanowiono zmienić powyższą regulację prawną.

Uzasadniając wprowadzenie nowego brzmienia art. 3 ust. 5 ustawy o podatkach i opłatach lokalnych, w odpowiedzi z dnia 4 września 2015 roku na interpelację poselską nr 34158 posłów Jana Warzechy i Bogdana Rzońcy ${ }^{27}$ Wiceminister Finansów Jarosław Neneman wskazał, iż: „znaczne powierzchnie budynków pozostają poza opodatkowaniem, przede wszystkim wskutek stosowania przez podatników, w szczególności w budynkach wielkopowierzchniowych, dopuszczalnej prawem optymalizacji podatkowej, prowadzącej do zmniejszenia wymiaru podatku od nieruchomości. Aktualne brzmienie przepisu umożliwia łatwe zmniejszenie ciężaru podatkowego - wystarczy wyodrębnić własność lokali oraz pozostawić odpowiednio dużą część wspólną, aby znacznie

\footnotetext{
${ }^{25}$ Stan prawny do dnia 31 grudnia 2015 roku - przyp. aut.

${ }^{26}$ Zob. uzasadnienie do rządowego projektu ustawy i zmianie ustawy o samorządzie gminnym oraz o zmianie niektórych innych ustaw, druk nr 2656, źródło: http:// www.sejm.gov.pl/Sejm7.nsf/druk.xsp?nr=2656.

${ }^{27}$ Pismo znak: PL-LS.054.24.2015.
} 
Adam Mudław - Podatek od nieruchomości - aktualne problemy...

zmniejszyć obciążenie podatkiem od nieruchomości działalności gospodarczej prowadzonej w budynkach (np. centrach handlowych)".

W tym miejscu należy podkreślić, że ustawodawca nie zdecydował się na wprowadzenie przepisów przejściowych odnośnie nowelizowanego przepisu art. 3 ust. 5 ustawy o podatkach i opłatach lokalnych. Oznacza to, iż z dniem wejścia w życie ustawy zmieniającej, tj. z dniem 1 stycznia 2016 r. obowiązuje nowe brzmienie komentowanego przepisu. Do stanów prawnych, zaistniałych przed dniem 1 stycznia $2016 \mathrm{r}$. należy stosować art. 3 ust. 5 ustawy o podatkach i opłatach lokalnych w brzmieniu dotychczasowym.

Odnosząc się do prezentowanego wcześniej przykładu ${ }^{28}$, według nowej regulacji prawnej, sposób obliczenia powierzchni wspólnej podlegającej opodatkowaniu podatkiem od nieruchomości przedstawia się następująco:

$$
\begin{gathered}
60 \mathrm{~m}^{2} / 240 \mathrm{~m}^{2}=0,25=25 \%, \\
220 \mathrm{~m}^{2} \times 25 \%=55 \mathrm{~m}^{2} \text { (część wspólna budynku), } \\
500 \mathrm{~m}^{2} \times 25 \%=125 \mathrm{~m}^{2} \text { (grunt). }
\end{gathered}
$$

\section{Problemy ze stosowaniem przepisu w nowym brzmieniu}

Pomimo, iż nowe brzmienie art. 3 ust. 5 ustawy o podatkach i opłatach lokalnych nie budzi żadnych wątpliwości interpretacyjnych oraz jest bliższe logice, jak również intuicyjnemu rozumieniu przepisów przez podatników, stosowanie powyższej regulacji prawnej w praktyce rodzi wiele problemów.

Pierwszym z nich jest obowiązek dokonania korekty informacji w sprawie podatku od nieruchomości dla osób fizycznych. Ustawodawca nie wskazał terminu, w jakim taką korektę należały złożyć do

${ }^{28} \mathrm{~W}$ budynku znajdują się cztery jednakowe mieszkania o powierzchni użytkowej $60 \mathrm{~m}^{2}$ każdy. Powierzchnia użytkowa całego budynku wynosi $460 \mathrm{~m}^{2}$. Powierzchnia części wspólnych, na który składają się m.in. piwnice i poddasza użytkowe, to $220 \mathrm{~m}^{2}$. Do nieruchomości przynależy grunt będący współwłasnością właścicieli lokali o powierzchni $500 \mathrm{~m}^{2}$. 
właściwego organu podatkowego ${ }^{29}$. Przyjąć zatem należy, iż stosownie do treści art. 6 ust. 6 ustawy o podatkach i opłatach lokalnych osoby fizyczne powinny złożyć korektę informacji dla potrzeb podatku od nieruchomości w terminie 14 dni od dnia zaistnienia zdarzenia mającego wpływ na wysokość opodatkowania podatkiem od nieruchomości. W analizowanym przypadku zdarzeniem tym jest wejście z dniem 1 stycznia 2016 r. nowej reguły wyliczania podstawy opodatkowania podatkiem od nieruchomości części wspólnych - vide: art. 3 ust. 5 ustawy o podatkach i opłatach lokalnych.

Na marginesie wskazać należy, że problem korekty nie dotyczy osób prawnych oraz jednostek organizacyjnych nieposiadających osobowości prawnej, albowiem te, zgodnie z art. 6 ust. 9 ustawy o podatkach i opłatach lokalnych mają obowiązek złożenia do dnia 31 stycznia roku podatkowego stosownej deklaracji na podatek od nieruchomości. Deklaracje te składane są co roku, zatem już w samej deklaracji za rok 2016 powinny być zawarte dane wyliczone według nowego brzmienia art. 3 ust. 5 ustawy o podatkach i opłatach lokalnych.

Niestety sporządzenie korekty informacji w sprawie podatku od nieruchomości dla osób fizycznych, bądź deklaracji dla potrzeb tego podatku w przypadku podmiotów grupowych ${ }^{30}$ uzależnione jest od posiadania informacji na temat dwóch zmiennych: procentowego udziału właściciela nieruchomości w części wspólnej oraz powierzchni części wspólnej opodatkowanej podatkiem od nieruchomości. 0 ile pierwsza zmienna jest znana właścicielowi nieruchomości (wynika ona chociażby z umowy sprzedaży nieruchomości sporządzonej w formie aktu notarialnego), o tyle druga zmienna, tj. powierzchnia części wspólnych, nie jest ujawniana w żadnym dokumencie, którym dysponuje właściciel nieruchomości. Brak jest takiej informacji w umowie sprzedaży nieruchomości, jak również $\mathrm{w}$ księgach wieczystych prowadzonych przez sąd dla danej nieruchomości. Informacji o powierzchni części

${ }^{29}$ Właściwym organem podatkowym, stosownie do treści postanowień art. 1c ustawy o podatkach i opłatach lokalnych, jest wójt, burmistrz, prezydent miasta.

${ }^{30}$ Osób prawnych lub jednostek organizacyjnych nieposiadających osobowości prawnej. 
Adam Mudław - Podatek od nieruchomości - aktualne problemy...

wspólnej nie znajdziemy także w gminnych oraz powiatowych ewidencjach $^{31}$ prowadzonych dla posiadanej nieruchomości.

Kolejnym problemem przy stosowaniu powyższego przepisu jest konieczność znalezienia podmiotu, który będzie dysponował danymi o wielkości powierzchni części wspólnych. W praktyce to wspólnoty mieszkaniowe powinny poinformować poszczególnych właścicieli lokali o wielkości powierzchni części wspólnych podlegających opodatkowaniu podatkiem od nieruchomości, gdyż tylko one posiadają takie informacje. W tym miejscu przypomnieć należy, iż z zakresu opodatkowania wyłączone są powierzchnie klatek schodowych oraz szybów dźwigowych, jak również powierzchnie, których wysokość nie przekracza 1,40 m. Stosownie natomiast do treści art. 4 ust. 2 in principio ustawy o podatkach i opłatach lokalnych powierzchnię pomieszczeń lub ich części oraz część kondygnacji o wysokości w świetle od 1,40 m do 2,20 m zalicza się do powierzchni użytkowej budynku w 50\%.

Czynność przekazania stosownych informacji właścicielowi lokalu na temat wielkości powierzchni wspólnej jest czynnością zwykłego zarządu, o której mowa w art. 22 ust. 1 ustawy z dnia 24 czerwca 1994 r. o własności lokali ${ }^{32}$. Czynności zwykłego zarządu podejmuje zarząd samodzielnie.

Niestety wiele wspólnot mieszkaniowych nie przekazało stosownych informacji na temat wielkości powierzchni części wspólnych właścicielom lokali. Wprowadzając znowelizowaną regulację art. 3 ust. 5 ustawy o podatkach i opłatach lokalnych ustawodawca nie przewidział żadnego przepisu statuującego nałożenie takiego obowiązku na wspólnoty mieszkaniowe. Brak jest również wyznaczonego prawnie terminu, w którym wspólnota mieszkaniowa powinna przekazać stosowne informacji właścicielom lokali.

Powyższe mankamenty regulacji jednoznacznie uniemożliwiają dokonanie korekty informacji w sprawie podatku od nieruchomości

\footnotetext{
${ }^{31} \mathrm{~W}$ kwestii znaczenia ewidencji gruntów i budynków vide: Art. 4, Znaczenie danych zawartych w ewidencji gruntów dla ustalenia podstawy opodatkowania, Orzecznictwo, [w:] W. Morawski (red.), Podatek od nieruchomości w orzecznictwie sądów administracyjnych. Komentarz. Linie interpretacyjne, Warszawa 2013, Publikacje Elektroniczne ABC LEX Wolters Kluwer.

32 Tekst jednolity: Dz.U. z 2015 r., poz. 1892 z późn. zm.
} 
właścicielowi lokalu - osobie fizycznej, bądź prawidłowego sporządzenia deklaracji dla potrzeb podatku od nieruchomości w przypadku osób prawnych lub jednostek organizacyjnych nieposiadających osobowości prawnej.

W tym miejscu wskazać również należy, iż to podatnik ponosi odpowiedzialność za zobowiązanie podatkowe w podatku od nieruchomości, zatem bierność wspólnoty mieszkaniowej w przekazywaniu informacji dotyczących wielkości powierzchni części wspólnych nie zwalnia podatnika z tej odpowiedzialności. Stosownie do treści art. 26 ustawy z dnia 29 sierpnia 1997 roku Ordynacja podatkowa ${ }^{33}$ podatnik odpowiada całym swoim majątkiem za wynikające ze zobowiązań podatkowych podatki.

Inaczej, zdaniem autora niniejszego opracowania, jest z odpowiedzialnością karno-skarbową. Stosownie do treści art. $54 \S 1$ ustawy z dnia 10 września 1999 r. Kodeks karny skarbowy ${ }^{34}$ (dalej: k.k.s.) podatnik, który uchylając się od opodatkowania, nie ujawnia właściwemu organowi przedmiotu lub podstawy opodatkowania lub nie składa deklaracji, przez co naraża podatek na uszczuplenie, podlega karze grzywny do 720 stawek dziennych albo karze pozbawienia wolności, albo obu tym karom łącznie. Jednakże oceniając powyższe zaniechanie podatnika podatku od nieruchomości ${ }^{35}$ pod kątem odpowiedzialności karno-skarbowej sięgnąć należy do art. 1 k.k.s. Zgodnie z art. $1 \S 1$ k.k.s. odpowiedzialności karnej za przestępstwo skarbowe lub odpowiedzialności za wykroczenie skarbowe podlega ten tylko, kto popełnia czyn społecznie szkodliwy, zabroniony pod groźbą kary przez ustawę obowiązującą w czasie jego popełnienia. Nie popełnia przestępstwa skarbowego lub wykroczenia skarbowego sprawca czynu zabronionego, jeżeli nie można mu przypisać winy w czasie popełnienia czynu (zob. art. $1 \S 3$ k.k.s.). Celem postępowania karno-skarbowego jest przede wszystkim ustalenie czy został popełniony czyn zabroniony, wyjaśnienie okoliczności z tym związanych oraz ustalenie, kto ponosi

\footnotetext{
${ }^{33}$ Tekst jednolity: Dz.U. z 2017 r., poz. 201 z późn. zm.

${ }^{34}$ Tekst jednolity: Dz.U. z 2016 r., poz. 2137 z późn. zm.

${ }^{35} \mathrm{Tj}$. brak złożenia korekty informacji w sprawie podatku od nieruchomości.
} 
Adam Mudław - Podatek od nieruchomości - aktualne problemy...

winę za ten czyn. W analizowanym przypadku podatnik podatku od nieruchomości nie może ponosić odpowiedzialności karno-skarbowej za brak sporządzenia korekty informacji w sprawie podatku od nieruchomości z powodu nieprzekazania przez wspólnotę mieszkaniową danych, na podstawie których taką korektę można sporządzić. Podatnik nie ponosi winy za bierność wspólnoty mieszkaniowej, a to wyłącza jego odpowiedzialność karno-skarbową.

Postawić należy w tym miejscu pytanie, czy wspólnota mieszkaniowa, a ściślej mówiąc członkowie zarządu wspólnoty mieszkaniowej, mogą ponosić odpowiedzialność karną za niewykonywanie zadań nałożonych na nich przepisami powszechnie obowiązującego prawa. W dzisiejszym stanie prawnym jest to wysoce wątpliwe, albowiem żaden przepis powszechnie obowiązującego prawa nie nakłada expressis verbis na wspólnotę mieszkaniową (członków zarządu wspólnoty mieszkaniowej) obowiązku przekazywania informacji o wielkości powierzchni części wspólnych, co zostało wskazane już we wcześniejszych rozważaniach.

Kolejnym problemem, który powstaje przy stosowaniu znowelizowanego przepisu art. 3 ust. 5 ustawy o podatkach i opłatach lokalnych, jest kwestia weryfikacji przez organy podatkowe prawidłowości wyliczenia podstawy opodatkowania podatkiem od nieruchomości. W przypadku gdy podatnik nie skoryguje informacji w sprawie podatku od nieruchomości bądź złożona deklaracja dla potrzeb tego podatku nie będzie uwzględniała nowego sposobu liczenia proporcji przy opodatkowywaniu części wspólnych, organy podatkowe mogą przeprowadzić procedury weryfikacyjne, o których mowa w przepisach Ordynacji podatkowej. Są to: czynności sprawdzające (Dział V Ordynacji podatkowej), kontrola podatkowa (Dział VI Ordynacji podatkowej) oraz postępowanie podatkowe (Dział IV Ordynacji podatkowej).

W zdecydowanej większości przypadków brak jest jednak podstaw do przeprowadzania wskazanych czynności weryfikacyjnych, z uwagi na treść przepisu art. 6 ust. 8a ustawy o podatkach i opłatach lokalnych. Nie wszczyna się bowiem postępowania, a postępowanie wszczęte umarza, jeżeli wysokość zobowiązania podatkowego na dany rok 
podatkowy nie przekraczałaby, określonych na dzień 1 stycznia roku podatkowego, najniższych kosztów doręczenia w obrocie krajowym przesyłki poleconej za potwierdzeniem odbioru ${ }^{36}$ przez operatora wyznaczonego w rozumieniu ustawy z dnia 23 listopada 2012 r. - Prawo pocztowe $^{37}$. W takim przypadku decyzję umarzającą postępowanie pozostawia się w aktach sprawy, a organ jest nią związany od chwili wydania. Do zmiany decyzji umarzającej postępowanie przepis art. 254 ustawy z dnia 29 sierpnia 1997 r. Ordynacja podatkowa ${ }^{38}$ stosuje się odpowiednio.

Przepis art. 6 ust. 8a ustawy o podatkach i opłatach lokalnych wprowadzony został również z dniem 1 stycznia 2016 roku na mocy art. 9 pkt 6 lit. a) ustawy z dnia 25 czerwca 2015 r. o zmianie ustawy o samorządzie gminnym oraz niektórych innych ustaw ${ }^{39}$. Idea tego rozwiązania zgodna jest z przepisami ustawy z dnia 17 grudnia 2004 r. o odpowiedzialności za naruszenie dyscypliny finansów publicznych ${ }^{40}$, albowiem ogranicza ona kosztowne procedury weryfikacyjne, które z uwagi na niskie kwoty zobowiązań podatkowych nie zostaną nimi zrekompensowane.

W praktyce należy wskazać, że w przypadku mieszkań nieprzekraczających $50 \mathrm{~m}^{2}-60 \mathrm{~m}^{2}$ w dużych wspólnotach mieszkaniowych (tj. liczących powyżej 7 lokali) w nowym budownictwie, bądź budownictwie z tzw. wielkiej płyty, różnica w naliczaniu podatku od nieruchomości wynosi kilka złotych rocznie ${ }^{41}$. Przyczyną tego stanu rzeczy jest zminimalizowanie przez projektantów części wspólnych budynków. W starym budownictwie, w którym podpiwniczone są całe budynki, oraz w których najczęściej występują strychy nad całym budynkiem,

${ }^{36}$ Od 1 lutego 2017 roku, zgodnie z Cennikiem Usług Powszechnych w obrocie krajowym najniższa wartość kosztów doręczenia w obrocie krajowym przesyłki poleconej za potwierdzeniem odbioru to 7,80 zł - vide: s. 3 i 6 Cennika.

${ }^{37}$ Tekst jednolity: Dz.U. z 2017 r., poz. 1481.

38 Tekst jednolity: Dz.U. z 2017 r., poz. 201 z późn. zm.

${ }^{39}$ Dz.U. z 2015 r., poz. 1045.

${ }^{40}$ Tekst jednolity: Dz.U. z 2017 r., poz. 1311.

${ }^{41}$ Por. Odpowiedź Wiceministra Finansów Jarosława Nenemana z dnia 4 września 2015 roku na interpelację poselską nr 34158 posła Jana Warzechy i posła Bogdana Rzońcy (pismo znak: PL-LS.054.24.2015). 
Adam Mudław - Podatek od nieruchomości - aktualne problemy...

różnice te będą o wiele większe. Powodem tego jest duża powierzchnia stanowiąca cześć wspólną budynku. Najbardziej odczuwalna zmiana w naliczaniu podatku od nieruchomości dotyczy przedsiębiorców, w szczególności tych, którzy są właścicielami powierzchni w domach towarowych lub centrach handlowych. W tego typu obiektach część wspólna nieruchomości, na którą składają się szerokie i przestronne ciągi komunikacyjne, jak również duże parkingi, stanowi spory odsetek powierzchni całkowitej nieruchomości, a w konsekwencji wpływa na zwiększenie obciążenia podatkiem od nieruchomości właścicieli poszczególnych lokali w zakresie części wspólnych. Przypomnieć należy, że stosownie do treści obwieszczenia Ministra Finansów z dnia 28 lipca 2016 r. w sprawie górnych stawek kwotowych podatków i opłat lokalnych w 2017 roku $^{42}$ maksymalna stawka podatku od nieruchomości dla gruntów związanych z prowadzeniem działalności gospodarczej, bez względu na sposób zakwalifikowania w ewidencji gruntów i budynków wynosi 0,89 zł od $1 \mathrm{~m}^{2}$ powierzchni gruntu, natomiast maksymalna stawka tego podatku od budynków lub ich części związanych z prowadzeniem działalności gospodarczej oraz od budynków mieszkalnych lub ich części zajętych na prowadzenie działalności gospodarczej wynosi 22,66 zł od $1 \mathrm{~m}^{2}$ powierzchni użytkowej. W konsekwencji nowe przepisy uniemożliwiają optymalizację podatkową dla przedsiębiorców mających lokale w centrach handlowych, na którą wskazywał Wiceminister Finansów J. Neneman w cytowanej odpowiedzi z dnia 4 września 2015 r. na interpelację poselską.

\section{Podsumowanie}

Reasumując wskazać należy, że nowe brzmienie przepisu art. 3 ust. 5 ustawy o podatkach i opłatach lokalnych pozwala na pełne opodatkowanie części wspólnych nieruchomości. Pomimo, iż w zdecydowanej większości przypadków jest ono niekorzystne dla osób prowadzących działalność gospodarczą, ponieważ prowadzi do znacznego

\footnotetext{
${ }^{42}$ M.P. z 2016 r., poz. 779.
} 
obciążenia podatkiem od nieruchomości, konstrukcja przyjęta przez ustawodawcę jest prosta i intuicyjna. Poprzez odwołanie do art. 3 ustawy o własności lokali, ustawodawca ujednolicił przepisy zarówno na płaszczyźnie prawa podatkowego, jak i prawa cywilnego. Zrezygnowano z tworzenia sztucznej konstrukcji ${ }^{43}$, która pozwalała na pominięcie opodatkowania części nieruchomości wspólnej.

Niestety, stosowanie przepisu art. 3 ust. 5 ustawy o podatkach i opłatach lokalnych w nowym brzmieniu rodzi wiele wątpliwości, przedstawionych $\mathrm{w}$ niniejszym artykule, jednakże nie wynikają one z treści znowelizowanego przepisu, a jedynie z braku przepisów przejściowych, które by nakładały na wspólnoty mieszkaniowe obowiązek przekazywania właścicielom lokali (tj. członkom wspólnoty mieszkaniowej) informacji dotyczącej wielkości powierzchni części wspólnych oraz określałyby termin, w jakim zobligowane są to uczynić.

\section{Bibliografia:}

Borszowski P., Art. 3 [w:] Komentarz do ustawy o podatkach i opłatach lokalnych, [w:] Podatki i opłaty lokalne. Podatek rolny. Podatek leśny. Komentarz, Wyd. Wolters Kluwer, Warszawa 2016, Publikacje Elektroniczne ABC LEX Wolters Kluwer.

Dauter B. (red.), Podatki i opłaty lokalne, Podatek rolny, Podatek leśny, Wyd. Lexis Nexis, Warszawa 2009.

Etel L. [w:] Etel L., Presnarowicz S., Dudar G., Podatki i opłaty lokalne, Podatek rolny, Podatek leśny. Komentarz, Wyd. ABC a Wolters Kluwer business, Warszawa 2008.

Etel L., 20 lat ustawy o podatkach i opłatach lokalnych - kilka refleksji, „Przegląd Podatkowy" 2011, nr 4.

Kupień Ł., Opodatkowanie części wspólnej nieruchomości od 1 stycznia 2016 roku, Publikacje Elektroniczne ABC LEX Wolters Kluwer.

Morawski W. (red.), Ustawa o podatkach i opłatach lokalnych. Komentarz, Wyd. ODDK Gdańsk, 2013,

${ }^{43}$ Proporcja w zakresie odpowiadającym częściom ułamkowym wynikającym ze stosunku powierzchni użytkowej lokalu do powierzchni użytkowej całego budynku. 
Adam Mudław - Podatek od nieruchomości - aktualne problemy...

Morawski W. (red.), Podatek od nieruchomości w orzecznictwie sq̨dów administracyjnych. Komentarz. Linie interpretacyjne, Wyd. LEX, Warszawa 2013, Publikacje Elektroniczne ABC LEX Wolters Kluwer,

Morawski W., Zmiany w regulacji podatku od nieruchomości w 2016 roku drobne remonty w skansenie, „Przegląd Podatkowy” 2016, nr 11.

Odpowiedź Wiceministra Finansów Jarosława Nenemana z dnia 4 września 2015 r. na interpelację poselską nr 34158 posła Jana Warzechy i posła Bogdana Rzońcy (pismo znak: PL-LS.054.24.2015).

Uzasadnienie do rządowego projektu ustawy i zmianie ustawy o samorządzie gminnym oraz o zmianie niektórych innych ustaw, Druk nr 2656, źródło: http://www.sejm.gov.pl/Sejm7.nsf/druk.xsp?nr=2656. 